\section{Enhanced Biohydrogen Production from Sewage Sludge with Alkaline Pretreatment}

\author{
MULIN CAI, JUNXIN LIU, * AND \\ YUANSONG WEI \\ Department of Water Pollution Control Technology, \\ Research Center for Eco-Environmental Sciences, \\ Chinese Academy of Sciences, P.O. Box 2871, \\ Beijing 100085, People's Republic of China
}

Batch tests were carried out to analyze influences of the alkaline pretreatment and initial pH value on biohydrogen production from sewage sludge. Experimental results of the impact of different initial pH on biohydrogen production showed that both the maximal hydrogen yield occurred and that no methane was detected in the tests of at the initial $\mathrm{pH}$ of 11.0. The final $\mathrm{pH}$ decreased at the initial pH of $7.0-12.5$ but inc reased at the initial pH of 3.0-6.0, probably due to the combination of solubilized protein from sludge and the formation of volatile fatty acids (VFAs) and ammonia during biohydrogen fermentation. The performance of biohydrogen production using the raw sludge and the alkaline pretreated sludge was then compared in batch fermentation tests at the initial pH of 11.0. The hydrogen yield was increased from $9.1 \mathrm{~mL}$ of $\mathrm{H}_{2} / \mathrm{g}$ of dry solids (DS) of the raw sludge to $16.6 \mathrm{~mL}$ of $\mathrm{H}_{2} / \mathrm{g}$ of $\mathrm{DS}$ of the alkaline pretreated sludge. No methane and less carbon dioxide $(0.8 \%$ of control) were present in the biohydrogen production from the alkaline pretreated sludge. These results clearly showed that biohydrogen production could be enhanced and maintained stable by the combination of the high initial $\mathrm{pH}$ and alkaline pretreatment. The mechanism of biohydrogen production from sewage sludge at high initial $\mathrm{pH}$ was therefore investigated because the results of this study were different from previous studies of biohydrogen production. Results showed that protein was the major substrate for biohydrogen production from sewage sludge and that Eubacterium multiforme and Paenibacillus polymyxa were the dominant bacteria in biohydrogen production from alkaline pretreated sludge at an initial pH of 11.0. The combination of alkaline pretreatment and high initial $\mathrm{pH}$ could not only maintain a suitable $\mathrm{pH}$ range for the grow th of dominant hydrogen-producing anaerobes but also inhibit the growth of hydrogen-consuming anaerobes. In addition, the changes in $\mathrm{pH}$ value, oxidationreduction potential, VFAs and soluble COD during hydrogen fermentation were also discussed.

\section{Introduction}

Hydrogen is known as a clean renewable energy source because its product of reaction with oxygen is only $\mathrm{H}_{2} \mathrm{O}$. Hydrogen has a high-energy yield of $142.35 \mathrm{~kJ} / \mathrm{g}, 2.75$ times than that of any hydrocarbons $(1,2)$. Hydrogen generation

*Corresponding author telephone/fax: +86-10-62849133; email: jxliu@mail.rcees.ac.cn.

10.1021/es0349204 CCC: $\$ 27.50$ Published on Web 04/28/2004 can be classified into two ways: chemical-physical and biological methods. The chemical-physical methods (e.g., through fossil fuel processing, water electrolysis using solar power) are energy-intensive and expensive (3). In contrast, the biological methods are environmentally favorable and consume less energy.

The biological wastewater treatment processes are used worldwide. However, large amounts of sewage sludge are produced from these biological processes. In 2001, about 4.22 billion t of municipal wastewater was treated in more than 150 municipal wastewater treatment plants in China, producing about $0.55-1.06$ million t of dry sludge (4). Generally, the wasted sludge is treated by the anaerobic digestion process to produce methane. Hydrogen is found as an important intermediate product in the anaerobic digestion (5). Many investigations have shown that various wastes containing high organic matter have been used to produce hydrogen gas by anaerobic fermentation process (6-10). The sewage sludge is rich in polysaccharides and proteins and thus is a potential substrate for hydrogen production. Recently, some studuies are focusing on using the sludge to produce hydrogen by anaerobic fermentation. Due to low hydrogen yield from the raw sewage sludge (i.e., $0.16 \mathrm{mg}$ of $\mathrm{H}_{2} / \mathrm{g}$ of dried solids (DS)), several methods of sludge pretreatment such as ultrasonication, acidification, sterilization, and freezing-and-thawing have been introduced to enhance the hydrogen yield. Hydrogen yields were improved to $1.4 \mathrm{mg} \mathrm{H}_{2} / \mathrm{g}$ of DS using the boiled sludge and to $1.5 \sim 2.1 \mathrm{mmol}$ of $\mathrm{H}_{2} / \mathrm{g}$ of COD with sludge pretreated by sterilization or freezing-and-thawing (11). However, pure culture method was used in most studies for biohydrogen production (11-15) and thus made the biohydrogen production process more complicated because of necessary sterilization. Therefore, microflora enriched from a natural population of bacteria by various methods such as heatshocking and acid-base treatment are currently used in biohydrogen production studies $(2,5-7,17)$.

It is generally thought that theanaerobic digestion process of organic wastewater or waste biosolids goes through three stages: hydrolysis, acidification, and methane production. Hydrogen production occurs in the acidification stage, and the $\mathrm{pH}$ value is one of important factors affecting the biohydrogen fermentation. In general, theoptimal initial $\mathrm{pH}$ of biohydrogen fermentation is thought to be between 5.0 and $6.0(2,16,17)$. However, Lee et al. reported an unusual result in which the optimal $\mathrm{pH}$ was 9.0 for the batch biohydrogen fermentation of sucrose (18). Further study is therefore needed on the impact of the initial $\mathrm{pH}$ of sewage sludge on biohydrogen fermentation from organic wastes. It is well-known that hydrogen producers and hydrogen consumers inhabit together in the sewage sludge during biohydrogen production. Hydrogen produced can be consumed when hydrogen consumers grow well during the anaerobic digestion. Although many methods such as controlling low $\mathrm{pH}$, short sludge retention time (SRT), and heat-shocking treatment have been investigated to inhibit the hydrogen consumption during biohydrogen production $(2,6,7,17)$, a problem of quick consumption of hydrogen produced still exists in biohydrogen production from sewage sludge $(11,12)$. This phenomenon results in difficulty in maintaining high and stable hydrogen production and then limits theapplication of biohydrogen production from sewage sludge.

The purposes of this study were to obtain a stable and high biohydrogen production from sewage sludge without addition of any pure hydrogen-producing seed bacteria or 


\section{TABLE 1. Characteristics of the Sewage Sludge}

\begin{tabular}{lcc}
\multicolumn{1}{c}{ items } & range & average \pm SD \\
pH & $7.01-7.61$ & $7.25 \pm 0.25$ \\
TSS (g/L) & $10.36-13.33$ & $12.11 \pm 1.22$ \\
VSS (g/L) & $5.83-8.47$ & $7.05 \pm 0.97$ \\
VSS/TSS & $0.56-0.64$ & $0.58 \pm 0.03$ \\
SCOD (mg/L) & $44.23-128.30$ & $99.13 \pm 33.81$ \\
TCOD (mg/L) & $9482-12885$ & $11517 \pm 1255$ \\
SCOD/TCOD (\%) & $0.5-1.04$ & $1.10 \pm 0.26$
\end{tabular}

nutrient sources. Therefore, this study first investigated the impact of the initial $\mathrm{pH}$ value of sewage sludge on biohydrogen production and then compared the performances of biohydrogen production usingtheraw sludgeand thealkaline pretreated sludge. In addition, the mechanisms of biohydrogen production in this case were also discussed.

\section{Materials and Methods}

Sewage Sludge. The sewage sludge was obtained from the aeration tank of a municipal wastewater treatment plant in Beijing. The design capacity of the aeration tank is 30000 $\mathrm{m}^{3} / \mathrm{d}$. Thesludge was first concentrated by settling for about $24 \mathrm{~h}$. I ts characteristics are listed in Table 1.

Alkaline Pretreatment. The concentrated sludge was pretreated with the slow addition of alkali of $4 \mathrm{M}$ sodium hydroxide, and the $\mathrm{pH}$ value was controlled at 12.0. After alkaline addition, the sludge was further stirred for $30 \mathrm{~min}$ and then placed in a temperature-controlled cabin at $25^{\circ} \mathrm{C}$ for $24 \mathrm{~h}$.

Batch Fermentation Tests. Batch experiments of biohydrogen production from sewage sludge by fermentation were carried out using serum vials with a working volume of $125 \mathrm{~mL}$. The tested sludge, with or without alkaline pretreatment, was sampled at $50 \mathrm{~mL}$ and then put in the vial. The test using the raw sludge was set as the control. The initial $\mathrm{pH}$ values of sludge in other tests were adjusted from 3.0 to 12.5 , respectively, by slowly adding $3 \mathrm{M}$ hydrochloric acid or $2 \mathrm{M}$ sodium hydroxide. No extra nutrients wereadded into the tested sludge. Oxygen in the vials was removed from the headspace by nitrogen gas sparging for $20 \mathrm{~s}$. The vials were then capped with rubber stoppers and placed in a airbath shaker $(150 \mathrm{rpm})$ at $36 \pm 1^{\circ} \mathrm{C}$. Tests of each initial $\mathrm{pH}$ value were carried out in triplicate. At each time interval, the total gas volume was measured by releasing the pressure in the bottles using a glass syringe $(5-50 \mathrm{~mL})$ to equilibrate with the room pressure as in the Owen method (19), and then the hydrogen concentration was determined.

The biohydrogen fermentation using the sludge with or without alkaline pretreatment was compared at the same initial $\mathrm{pH}$ value of 11.0. To avoid possible error during sampling, three serum bottles were chosen randomly for analyzing the gas and liquid components and then discarded after analysis at each time interval. In addition, tests were conducted to understand the changes of organic matter during biohydrogen fermentation using the raw sludge and the alkaline pretreated sludge at initial $\mathrm{pH}$ values of 5.0 and 11.0 , respectively.

Analysis. Hydrogen concentration was measured by a gas chromatograph (GC122, China) equipped with a thermal conductivity detector (TCD) and a 2-m stainless column (activated carbon, 60-80 mesh). The temperatures of the injection, column, and detector were set at 70, 140, and 140 ${ }^{\circ} \mathrm{C}$, respectively. Nitrogen was used as the carrier gas at the flow rate of $30 \mathrm{~mL} / \mathrm{min}$. Methane and carbon dioxide were also determined with the same GC-TCD and a 2-m stainless column filled with PorapakT (80-100 mesh). Theoperational temperatures of the injection port, theoven, and the detector were set at 110,60 , and $200^{\circ} \mathrm{C}$, respectively. $\mathrm{H}_{2}$ was used as the carrier gas at a flow rate of $40 \mathrm{~mL} / \mathrm{min}$. The gas in the headspace of serum bottles was sampled with a 0.1-mL gastight syringe and measured by comparing the sample biogas with standard hydrogen or standard $\mathrm{CH}_{4} / \mathrm{CO}_{2}$ gas. The concentrations of the volatile fatty acids (VFAs) were analyzed with the filtrate samples through a $0.45-\mathrm{mm}$ membrane using a Shimadzu GC-9A (Japan) gas chromatograph equipped with a flame ionization detector (FID) and a 2-m glass column packed with Chromosorb 101 (60-80 mesh). The temperatures of the injection port, the detector, and the column were set at 250,250 , and $170^{\circ} \mathrm{C}$, and nitrogen was the carrier gas at the flow rate of $50 \mathrm{~mL} / \mathrm{min}$.

The oxidation-reduction potential (ORP) value was determined by a pH meter pH330i (WTW, Germany) equipped with a SenTix-ORP electrode. The $\mathrm{pH}$ value was measured by a pH meter (PHS-3C, China). The soluble COD (SCOD) and total COD (TCOD) were analyzed by a CTL-12 COD meter (Huatong Company, China). TheSCOD, protein, and carbohydrate concentrations were measured with the filtrate samples through a $0.45-\mathrm{mm}$ membrane. Protein was determined by the Lowry method using bovine al bumin as the standard (21), while carbohydrate was measured by the phenol sulfuric acid method using glucose as the standard (22), and lipid was analyzed after ether extraction of the supernatant. The concentrations of total suspended solids (TSS) and volatile suspended solids (VSS) were determined by a $10-\mathrm{mL}$ sample at $105{ }^{\circ} \mathrm{C}(4 \mathrm{~h})$ and $600{ }^{\circ} \mathrm{C}(2 \mathrm{~h})$, respectively.

Dominant bacteria screening and identification were carried out using two culture media according to methods described in Zhu et al. (20). Photomicrographs of dominant bacteria weretaken by a scanning electron microscopy (SEM) (Philips Feiquanta-200) and a transition electron microscopy (TEM) (Hitachi S-600), respectively.

The accumulative volume of hydrogen produced $(\mathrm{H})$ over the time course during the batch tests was fitted with the Gompertz equation (7):

$$
H=P \exp \left\{-\exp \left[\frac{R_{m} e}{P}(\lambda-t)+1\right]\right\}
$$

where $P$ is the hydrogen potential $(m L), R_{m}$ is the maximum hydrogen production rate $(\mathrm{mL} / \mathrm{h}), \lambda$ is thelag phase time $(h)$, and eis 2.718281828 . In this paper, $R_{m}$ is expressed as $\mathrm{mL}$ of $\mathrm{H}_{2} /\left(\mathrm{g}\right.$ of DS $\left.\mathrm{h}^{-1}\right)$, and the specific hydrogen production potential $\left(P_{s}\right)$ is defined as $\mathrm{mL}$ of $\mathrm{H}_{2} / \mathrm{g}$ of DS. Both Gompertz equation fit and Pearson correlationship analysis werecarried out using SPSS 10.0 (SPSS Inc., USA). In this paper, the data before the peak point of the hydrogen profiles were fitted by the Gompert equation because of its suitability for the profile of no gas consumption.

\section{Results and Discussion}

Impacts of Initial pH on Hydrogen Production. In thisstudy, the influence of initial $\mathrm{pH}$ on hydrogen production from the raw sludge by anaerobic fermentation was first investigated (Figure 1). After about $6 \mathrm{~h}$, the system started to produce hydrogen in all the tests except those at the initial $\mathrm{pH}$ of 3.0, 4.0 (data not shown in Figure 1), 5.0, and 6.0 and the control. A significant increase of hydrogen production was observed at the initial $\mathrm{pH}$ values from 10.0 to 11.5 , and the maximal yield of $8.1 \mathrm{~mL} / \mathrm{g}$ of DS occurred at the initial $\mathrm{pH}$ value of 11.0 after 24-h fermentation. However, hydrogen accumulated in the headspace of bottles was then consumed by hydrogen consumers in the followingfermentation time. The consumption of hydrogen gas was as the following order of initial pH values: $12.0<11.5<11.0<10.5<10.0<9.0$. Although thehydrogen at the initial $\mathrm{pH}$ of 12.0 was consumed slower than that at other $\mathrm{pH}$ values, it had longer lag time (about $22 \mathrm{~h}$ ) than other tests. These results clearly showed 


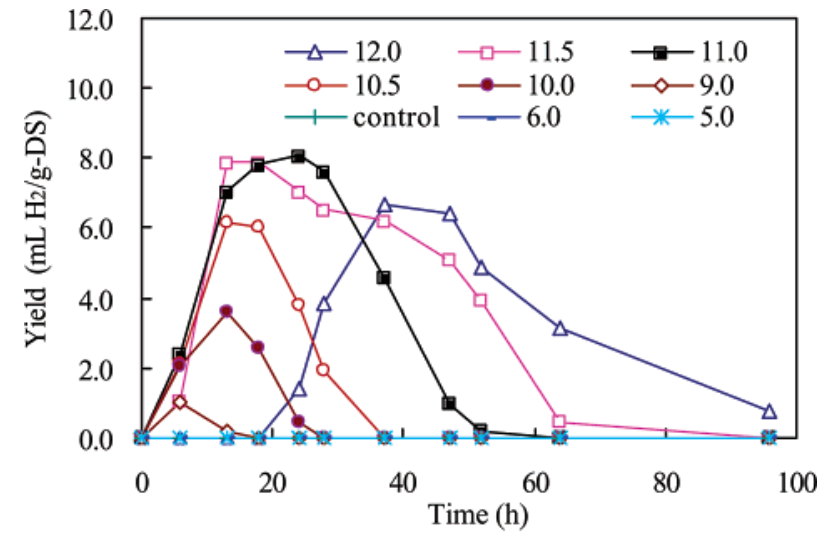

FIGURE 1. Profiles of hydrogen yield at different initial $\mathrm{pH}$ values using the raw sludge (TSS $=10.36 \mathrm{~g} / \mathrm{L}$ ).
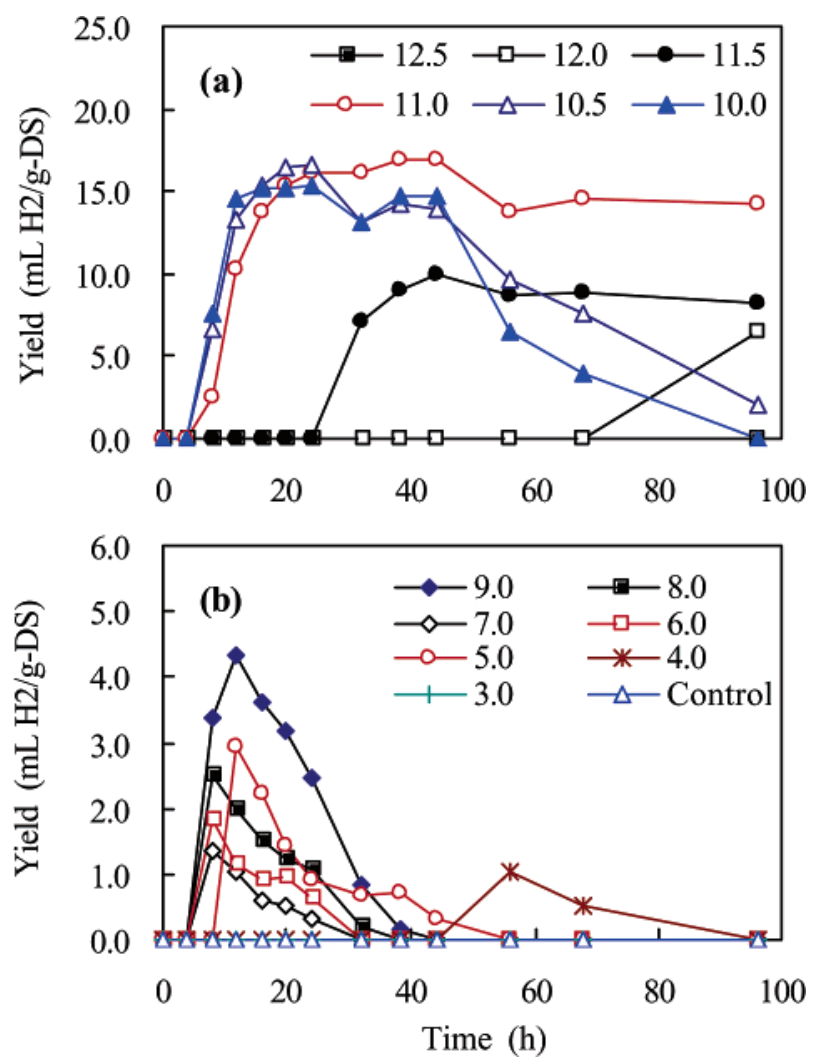

FIGURE 2. Hydrogen yield at different initial $\mathrm{pH}$ values (a) from 10.0 to 12.5 and (b) from 3.0 to 9.0 using the alkaline pretreated sludge (TSS $=10.97 \mathrm{~g} / \mathrm{L}$ ).

that the high initial pH value of the tested sludgewas effective for biohydrogen production and that the hydrogen-producing bacteria might resist a high $\mathrm{pH}$ condition.

The al kal ine pretreated sludge was then used for biohydrogen production at different initial $\mathrm{pH}$ values from 3.0 to 12.5 (Figure 2). Compared with hydrogen production from the raw sludge (Figure 1 ), hydrogen production in the tests of initial $\mathrm{pH}$ values at $10.0,10.5$, and 11.0 markedly increased and stayed longer time (e.g., hydrogen in the tests of initial $\mathrm{pH}$ at 10.0 and 10.5 began to decrease after about $44 \mathrm{~h}$ ) (Figure 2). The maximal hydrogen yield $(16.9 \mathrm{~mL} / \mathrm{g}$ of $\mathrm{DS})$ in the tests using the alkaline pretreated sludge occurred at initial $\mathrm{pH}$ of 11.0 after $40-\mathrm{h}$ fermentation. It is noted that few hydrogen were consumed in the test at initial pH of 11.0. Hydrogen production also happened in the tests of $\mathrm{pH}$ at 11.5 and 12.0 , respectively, but the lag phases were too long, about 25 and $77 \mathrm{~h}$, respectively. Biohydrogen production
TABLE 2. Estimated Values of Parameters in the Modified Gompertz Equation

\begin{tabular}{|c|c|c|c|c|}
\hline initial pH & $P_{\mathrm{s}}$ & $R_{\mathrm{m}}$ & $\lambda$ & $R^{2}$ \\
\hline \multicolumn{5}{|c|}{ Raw Sludge } \\
\hline control & & & & \\
\hline 10.0 & 3.629 & 1.364 & 4.468 & 1.000 \\
\hline 10.5 & 6.063 & 6.208 & 5.658 & 0.999 \\
\hline 11.0 & 8.082 & 0.906 & 3.341 & 1.000 \\
\hline 11.5 & 7.886 & 2.486 & 5.656 & 1.000 \\
\hline 12.0 & 6.601 & 0.687 & 22.041 & 0.998 \\
\hline \multicolumn{5}{|c|}{ Alkaline Pretreated Sludge } \\
\hline control & & & & \\
\hline 4.0 & 1.266 & 1.119 & 54.947 & 1.000 \\
\hline 5.0 & 4.429 & 1.484 & 9.921 & 1.000 \\
\hline 6.0 & 1.840 & 1.258 & 4.953 & 1.000 \\
\hline 7.0 & 1.341 & 1.078 & 4.838 & 1.000 \\
\hline 8.0 & 3.811 & 1.393 & 6.104 & 1.000 \\
\hline 9.0 & 4.363 & 1.791 & 5.870 & 1.000 \\
\hline 10.0 & 15.298 & 3.678 & 5.902 & 1.000 \\
\hline 10.5 & 16.477 & 2.214 & 5.041 & 0.999 \\
\hline 11.0 & 16.428 & 1.854 & 6.588 & 0.997 \\
\hline 11.5 & 9.805 & 1.156 & 25.394 & 0.999 \\
\hline 12.0 & 6.880 & 0.518 & 77.144 & 1.000 \\
\hline \multicolumn{5}{|c|}{ Comparison Test } \\
\hline $11.0^{a}$ & 15.579 & 1.136 & 11.326 & 0.991 \\
\hline $11.0^{b}$ & 9.138 & 0.696 & 0.609 & 0.994 \\
\hline
\end{tabular}

from the sludge has an optimal range suitable for hydrogenproducing bacteria. Long lags in this study could be due to toxic effects of alkaline pretreatment, and it also could be due to timeto lower the $\mathrm{pH}$ into a range suitable for hydrogen production. In addition, the lower hydrogen yields and quick hydrogen consumption in the tests of initial $\mathrm{pH}$ from 4.0 to 9.0 were observed as compared with those in the tests of $\mathrm{pH}$ between 10.0 and 11.5 (Figure 2). No hydrogen was detected in the tests of initial $\mathrm{pH}$ at 3.0, 12.5, and the control test, respectively. Compared with hydrogen production from the raw sludge (Figure 1 ), the maximal hydrogen yield was enhanced from 8.1 to $16.9 \mathrm{~mL} / \mathrm{g}$ of DS.

A common phenomenon, higher hydrogen yields and slower hydrogen consumption occurring at high initial $\mathrm{pH}$ values, was observed in the tests using both the raw sludge and the alkaline pretreated sludge. However, hydrogen produced was consumed more quickly, and less hydrogen remained in the end of biohydrogen fermentation from the raw sludge as compared with that from the alkalinepretreated sludge at the same initial pH between 11.0 and 12.0 (Figures 1 and 2). These results showed that the biohydrogen production could be enhanced and maintained stable from sewage sludge with alkaline pretreatment. In addition, the estimated parameters of $P_{s}, R_{m}$, and $\lambda$ are quite consistent with these experimental data (Table 2 ). These batch experiments were repeated for several times, and the same results were found. In this case, the initial pH value of 11.0 was thus considered optimal for biohydrogen batch fermentation from the waste activated sludge.

Hydrogen Production of Comparison Tests. There was an increase in hydrogen production at the same initial $\mathrm{pH}$ of 11.0 due to alkaline pretreatment of the raw sludge (Figure 3). In the test using the raw sludge, the hydrogen produced early ( $0.6 \mathrm{~h}$ lag time), and the maximal hydrogen yield was $9.1 \pm 0.15 \mathrm{mLof}_{2} / \mathrm{g}$ of DS, but the hydrogen was consumed quickly. In contrast, the hydrogen production sharply increased after a longer lag period $(11.3 \mathrm{~h})$ and reached to the maximal yield of $16.6 \pm 0.4 \mathrm{~mL}$ of $\mathrm{H}_{2} / \mathrm{g}$ of DS at about $44 \mathrm{~h}$, and little hydrogen consumption occurred in the test using alkaline pretreated sludge(Figure 3). It was interestingly found that no methane was detected and that few carbon 
TABLE 3. Comparison of the Literature Data on Biohydrogen Production Using Different Substrates

\begin{tabular}{|c|c|c|c|c|c|c|}
\hline \multirow[b]{2}{*}{ ref } & \multirow[b]{2}{*}{ seed inocula } & \multirow[b]{2}{*}{ substrate } & \multirow[b]{2}{*}{ reactor } & \multicolumn{3}{|c|}{ maximal hydrogen yield } \\
\hline & & & & $\begin{array}{c}\mathrm{mL} \text { of } \mathrm{H}_{2} / \\
\mathrm{g} \text { of substrate }\end{array}$ & $\begin{array}{l}\mathrm{mg} \text { of } \mathrm{H}_{2} / \\
\mathrm{g} \text { of substrate }\end{array}$ & $\begin{array}{l}\mathrm{mg} \text { of } \mathrm{H}_{2} / \\
\mathrm{g} \text { of } \mathrm{COD}\end{array}$ \\
\hline this study & raw sludge & raw sludge & serum bottles & $9.13^{a}, 9.14^{b}$ & $0.81^{a}, 0.82^{b}$ & $0.90^{a}, 0.91^{b}$ \\
\hline this study & alkaline treated sludge & alkaline treated sludge & serum bottles & $16.59^{a}, 15.58^{b}$ & $1.48^{a}, 1.39^{b}$ & $1.65^{a}, 1.55^{b}$ \\
\hline 11 & digester sludge & waste activated sludge & batch reactor & $\mathrm{na}^{\mathrm{c}}$ & 0.16 & na \\
\hline 12 & C. bifermentans & waste activated sludge & serum bottles & na & 1.8 & 1.2 \\
\hline 11 & C. bifermentans & $\begin{array}{l}\text { freezing and thawing and sterilization } \\
\text { pretreatment activated sludge }\end{array}$ & serum bottles & na & na & $3.0-4.2$ \\
\hline 11 & boiling treated sludge & concentrate of boiling treated sludge & batch reactor & na & na & 1.42 \\
\hline 11 & boiling treated sludge & boiling treated sludge & batch reactor & na & 1.03 & 0.40 \\
\hline 24 & digester sludge & peptone & batch reactor & 15.23 & 1.36 & na \\
\hline 15 & Clostridium pure culture & glucose & CSTR & 293.7 & 26.4 & na \\
\hline 3 & soybean soil & glucose & CSTR & 177.9 & 16.0 & na \\
\hline
\end{tabular}

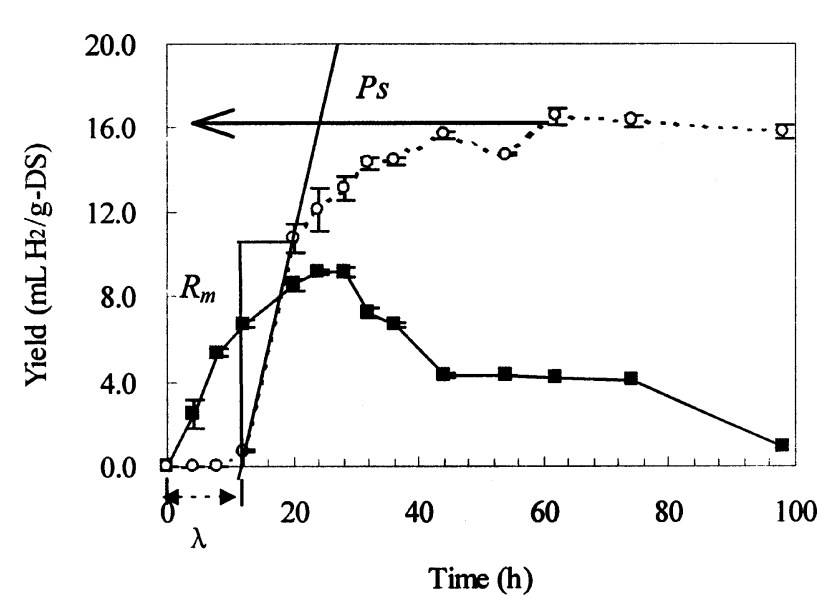

FIGURE 3. Hydrogen yields of comparison tests using the raw sludge and the alkaline pretreated sludge at the same initial pH of 11.0. Solid square: raw sludge. Open circle: alkaline pretreated sludge (TSS $=12.60 \mathrm{~g} / \mathrm{L}$ ).

dioxide (about $0.8 \%$ of the control) were present in both tests. Results of biohydrogen production in this study are compared with other results in the literature as shown in Table 3.

Methaneand Carbon DioxideProduction. Methaneand carbon dioxide production from the raw sludge and the al kal ine pretreated sludge at different initial $\mathrm{pH}$ values were also compared after 96-h anaerobic fermentation. For biohydrogen fermentation from theraw sludge, the methane yields ranged from 12.7 to $26.0 \mathrm{~mL}$ of $\mathrm{CH}_{4} / \mathrm{g}$ of DSin thetests of initial $\mathrm{pH}$ ranging from 5.0 to 10.0 , but no methane gas was detected in the other tests (Figure 4a). However, no methane gas was present in biohydrogen production from the alkaline pretreated sludge except that in the control test (Figure 4b). It is well-known that $\mathrm{H}_{2}$ is ubiquitous in the anaerobic environment but usually exhibits a fast turnover at very low hydrogen concentration (23). The hydrogenconsuming methanogenic bacteria can convert the formed hydrogen to methane if the methanogenesis step goes smoothly.

Although no methane gas was produced in the tests of initial $\mathrm{pH}$ ranging from 10.5 to 12.0 (Figure $4 \mathrm{a}$, raw sludge) and from 4.0 to 10.5 (Figure 4b, al kal ine pretreated sludge), hydrogen consumption still occurred in these tests (Figures 1 and 2). In addition, it was also found that high hydrogen yield, no methane detection, and less hydrogen consumption occurred in the test of using the alkaline pretreated sludge at the initial $\mathrm{pH}$ of 11.0. In general, hydrogen-producing anaerobes coexist with hydrogen-consuming bacteria in sewage sludge. Various types of hydrogen-consuming anaerobes, including methanogens, acetogens, and sulfate- reduc-
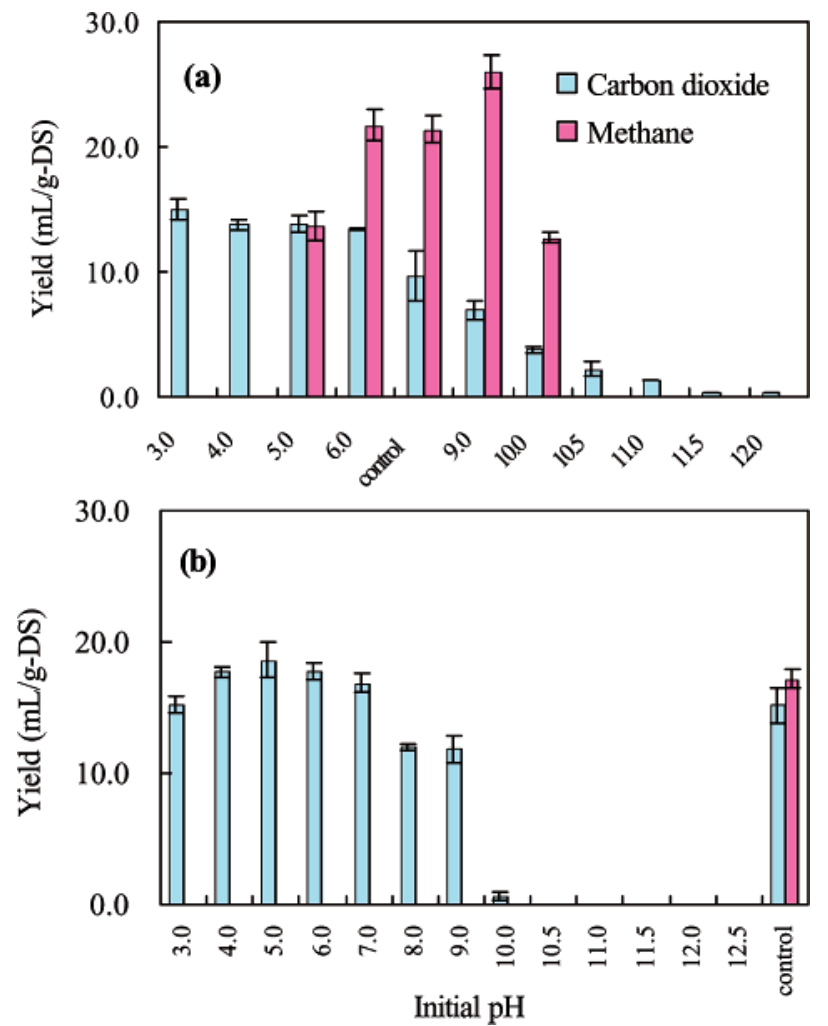

FIGURE 4. Profiles of methane and carbon dioxide yield using (a) the raw sludge and (b) the alkaline pretreated sludge.

ing bacteria can obtain energy by utilizing molecular hydrogen (24) as in eq 2. Hence it was no doubt that either

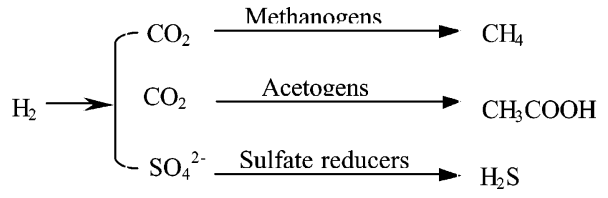

the alkaline pretreatment of sludge or the high initial $\mathrm{pH}$ heavily inhibited the growth of methanogenic bacteria but had little impact on the other hydrogen-consuming anaerobes.

As Figure 4 shows, the concentrations of $\mathrm{CO}_{2}$ decreased with the increasing of initial $\mathrm{pH}$ values, and almost no $\mathrm{CO}_{2}$ was detected in the tests of $\mathrm{pH}$ between 10.5 and 12.0. These results can be explained that the $\mathrm{CO}_{2}$ produced during biohydrogen fermentation is adsorbed by the sludge at high 

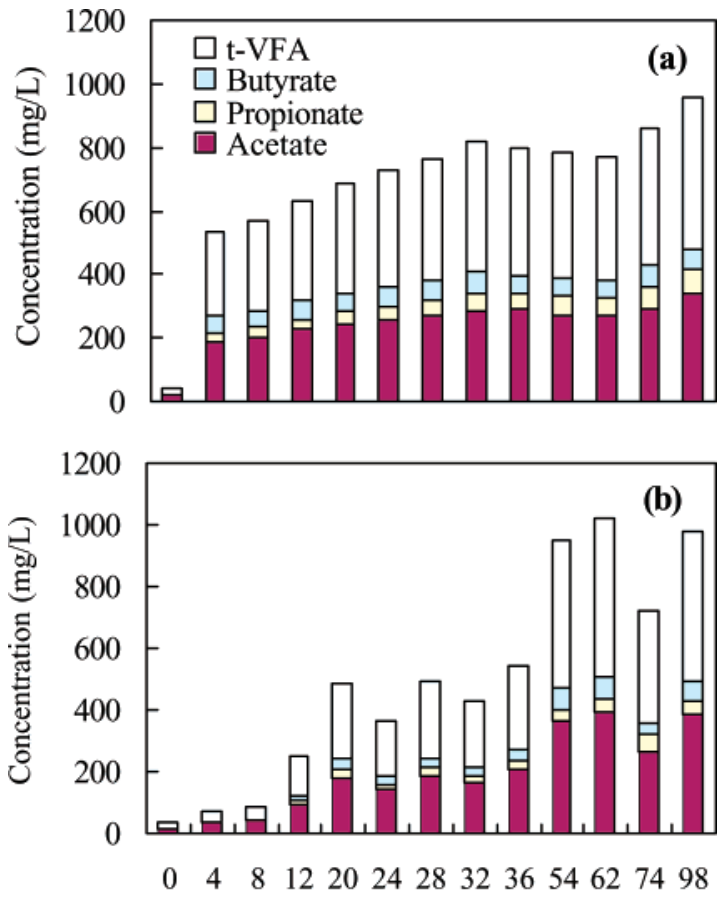

Time (h)

FIGURE 5. VFAs formation during hydrogen fermentation using (a) the raw sludge and (b) the alkaline pretreated sludge.

$\mathrm{pH}$. According to the carbonate equilibrium equation (eq 3):

$$
\mathrm{CO}_{2}+\mathrm{H}_{2} \mathrm{O} \Leftrightarrow \mathrm{HCO}_{3}^{-}+\mathrm{H}^{+}
$$

the higher the $\mathrm{pH}$, the more carbon dioxide is dissolved into the sludge. However, such phenomenon is helpful for the subsequent hydrogen gas purification process and improving the buffering potential capacity of the sludge.

Volatile Fatty Acids (VFAs). Hydrogen production was accompanied with the formation of volatile fatty acids (VFAs) throughout the sludge fermentation (Figure 5). In this study, the amounts of butyrate and propionate were very low in total VFAs, but acetate accounted for $70-80 \%$ of total VFAs (t-VFAs). This result is quite different from those in biohydrogen fermentation from glucose, in which VFAs mainly consists of butyrate and acetate $(5,7,17)$. Statistical analysis showed that the hydrogen yield was significantly correlated with acetate formation (Table 4). Cheng et al. demonstrated the similar result in the study of biohydrogen production by protein degradation (25). Therefore, these results might be dueto the fact that theorganic matter contained in thesewage sludge is mainly composed of protein (32-41\%), which is different from glucose or sucrose (26). So the metabolic mechanism of biohydrogen fermentation from sewage sludge may be different from that from glucose or sucrose, which will be discussed in the following text.

SCOD and Ratio of SCOD/TCOD. In the comparison test, the soluble COD (SCOD) of the raw sludge was comprised of only $1.38 \%$ of total COD (TCOD). After $24-\mathrm{h}$ fermentation, the SCOD increased to $12.9-18.1 \%$ of TCOD and maintained steady during the following $74 \mathrm{~h}$ (Figure 6). For the alkaline pretreated sludge, both the initial SCOD concentration $(2434.0 \mathrm{mg} / \mathrm{L})$ and the initial ratio of SCOD/TCOD (22.8\%) were much higher than those in the raw sludge (Figure 6). In addition, the ratio of SCOD/TCOD during biohydrogen production from the alkaline pretreated sludge gradually decreased with time, different from changes in the ratio of SCOD/TCOD during the test using the raw sludge. A combination of these results and biohydrogen production
TABLE 4. Pearson Correlations of VFAs and Hydrogen Yield during Biohydrogen Fermentation Tests ${ }^{\text {a }}$

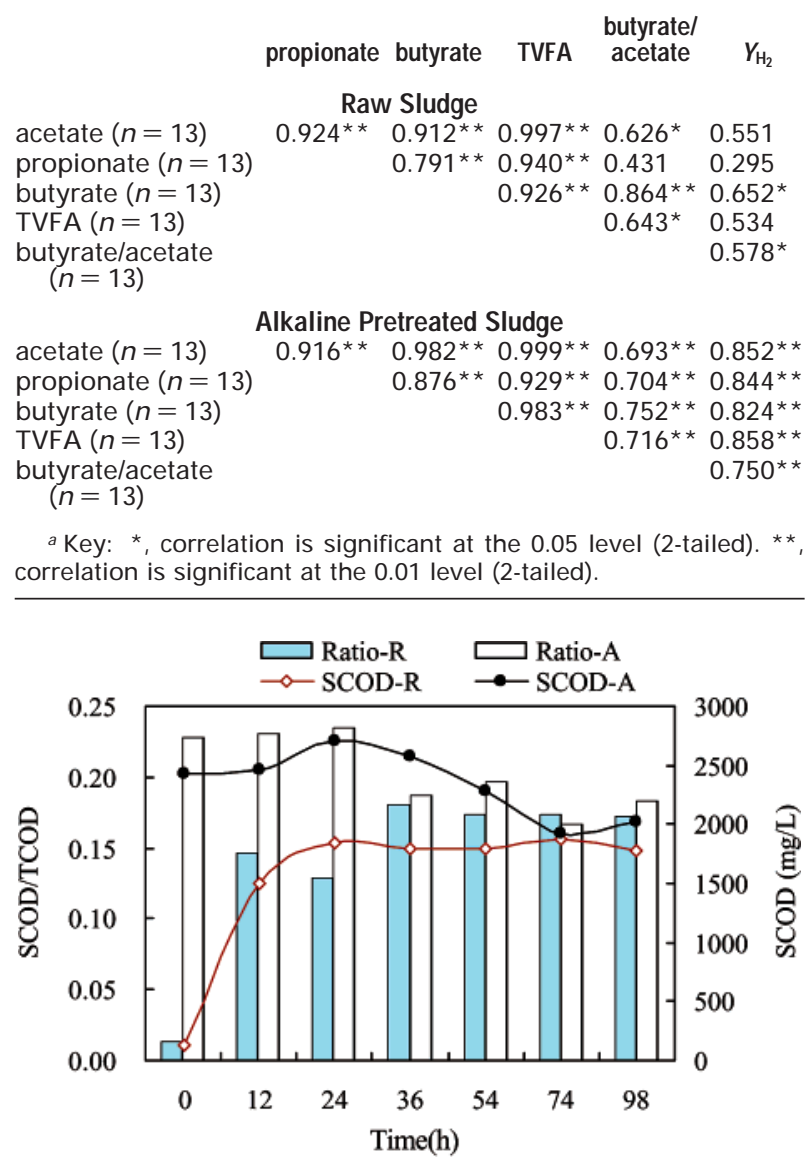

FIGURE 6. Changes of SCOD and SCOD/TCOD ratios during hydrogen fermentation using the raw sludge (R) and the alkaline pretreated sludge (A) at the initial $\mathrm{pH}$ of 11.0 .

TABLE 5. pH Changes in the End of Biohydrogen Fermentation at Different Initial pH Values

\begin{tabular}{ccccc}
\multicolumn{2}{c}{ raw sludge } & & \multicolumn{2}{c}{ alkaline pretreated sludge } \\
\cline { 1 - 2 } \cline { 5 - 5 } initial pH & final $\mathrm{pH}$ & & initial $\mathrm{pH}$ & final $\mathrm{pH}$ \\
3.0 & $4.83 \pm 0.67$ & & 3.0 & $4.08 \pm 0.06$ \\
4.0 & $6.30 \pm 0.02$ & & 4.0 & $5.45 \pm 0.00$ \\
5.0 & $6.59 \pm 0.02$ & & 5.0 & $5.84 \pm 0.01$ \\
6.0 & $6.90 \pm 0.02$ & & 6.0 & $6.24 \pm 0.04$ \\
control (7.35) & $7.13 \pm 0.03$ & & 7.0 & $6.72 \pm 0.04$ \\
9.0 & $7.62 \pm 0.06$ & & 8.0 & $7.11 \pm 0.08$ \\
10.0 & $8.12 \pm 0.08$ & & 9.0 & $7.16 \pm 0.06$ \\
10.5 & $8.53 \pm 0.03$ & & 10.0 & $8.61 \pm 0.04$ \\
11.0 & $8.80 \pm 0.10$ & & 10.5 & $9.09 \pm 0.06$ \\
11.5 & $9.38 \pm 0.09$ & & 11.0 & $9.43 \pm 0.07$ \\
12.0 & $10.12 \pm 0.02$ & & 11.5 & $9.63 \pm 0.12$ \\
& & & 12.0 & $10.23 \pm 0.05$ \\
& & & 12.5 & $12.27 \pm 0.05$ \\
& & control (7.02) & $6.79 \pm 0.06$ \\
\hline
\end{tabular}

revealed that the alkaline pretreatment was effective for solubilizing organic matter from sewagesludge and provided more bioavailable organic matter for hydrogen production from sewage sludge.

pH and ORP. The pH changes of biohydrogen fermentation from the raw sludge and the alkaline pretreated sludge are listed in Table 5. The final $\mathrm{pH}$ decreased at the initial $\mathrm{pH}$ of $7.0-12.5$ but increased at the initial $\mathrm{pH}$ of 3.0-6.0. This can be explained by the combination of solubilized protein 
TABLE 6. Concentrations of Organic Matters in Aqueous Phase of the Raw Sludge and the Alkaline Pretreated Sludge at Different Initial $\mathrm{pH}$

\begin{tabular}{|c|c|c|c|c|c|c|c|c|}
\hline & \multicolumn{3}{|c|}{ protein (mg/L) } & \multicolumn{3}{|c|}{ carbohydrate $(\mathrm{mg} / \mathrm{L})$} & \multicolumn{2}{|c|}{ lipid (mg/L) } \\
\hline & $\mathrm{pH} 3.0$ & pH 5.0 & $\mathrm{pH} 11.0$ & $\mathrm{pH} 3.0$ & pH 5.0 & $\mathrm{pH} 11.0$ & pH 5.0 & $\mathrm{pH} 11.0$ \\
\hline $\begin{array}{l}\text { raw sludge } \\
\text { alkaline pretreated sludge }^{b}\end{array}$ & 94.2 & $\begin{array}{r}71.5 \\
1037.5\end{array}$ & $\begin{array}{r}412.5 \\
1262.5\end{array}$ & 72.2 & $\begin{array}{r}50.1 \\
267.1\end{array}$ & $\begin{array}{l}160.9 \\
373.0\end{array}$ & $\begin{array}{r}46.0 \\
110.0\end{array}$ & $\begin{array}{r}68.0 \\
160.0\end{array}$ \\
\hline
\end{tabular}

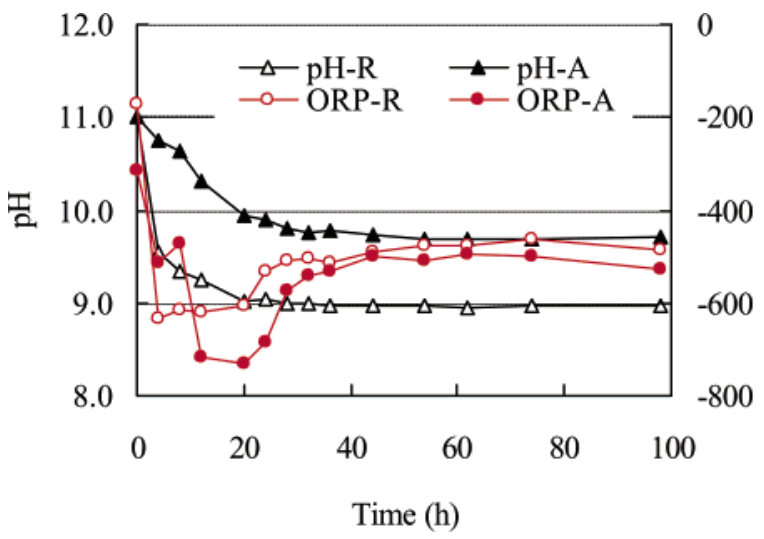

FIGURE 7. Changes of $\mathrm{pH}$ and ORP in the comparison tests using the raw sludge $(R)$ and the alkaline pretreated sludge $(A)$.

from sludge and the formation of VFAs and ammonia during biohydrogen fermentation. Protein is an amphoteric substance and has a large buffering capacity, but changes of soluble protein in thisstudy will be discussed in thefollowing text.

$\mathrm{pH}$ drops were also found in the comparison tests. The $\mathrm{pH}$ values decreased sharply in the first $20 \mathrm{~h}$ and then kept steady at about 9.0 and 9.7, respectively, during tests using both the raw sludge and the alkaline pretreated sludge at the initial $\mathrm{pH}$ of 11.0 (Figure 7). However, the $\mathrm{pH}$ drop in the biohydrogen fermentation from thealkalinepretreated sludge was lower than that from the raw sludge. On the basis of profiles of hydrogen production and $\mathrm{pH}$ changes, optimal $\mathrm{pH}$ values were around 9.5 and 10.0 for biohydrogen production from the raw sludge and the al kaline pretreated sludge, respectively.

The ORP value generally reflects the amount and type of oxidative-reductivesubstrates containing in theliquid. The most common hydrogen-producing bacteria contained in the sludge are kinds of strict anaerobic microorganisms (e.g., Clostridium sp.), which require a relative low ORP level between about -200 and $-250 \mathrm{mV}$. The ORP value was around $-300 \mathrm{mV}$ during the hydrogen fermentation from waste sludge by adding pure hydrogen-producing bacteria at neutral pH (11). Sung et al. (17) and Lin and Lay (27) also reported the ORP value of -320 to $-340 \mathrm{mV}$ and -311 to $-368 \mathrm{mV}$, respectively, in the biohydrogen production using sucrose as the substrate $(17,27)$. As shown in Figure 7 , the ORP values in this study dropped to a very low level $(-600$ to $-730 \mathrm{mV}$ ) during the first $24 \mathrm{~h}$ (this period corresponded with maximal hydrogen production) and then roseand stayed stable at around $-500 \mathrm{mV}$, much lower than those in studies cited above. This difference might be due to the high initial $\mathrm{pH}$ adopted in this study.

Investigation of Mechanism of Hydrogen Production at High Initial pH. In our study, the higher hydrogen yield was obtained at the high initial $\mathrm{pH}$ of $10.0-11.0$ as compared with those at the initial $\mathrm{pH}$ range of 3.0-8.0. These results are somehow different from all existing studies on biohydrogen production. It is therefore necessary to know the
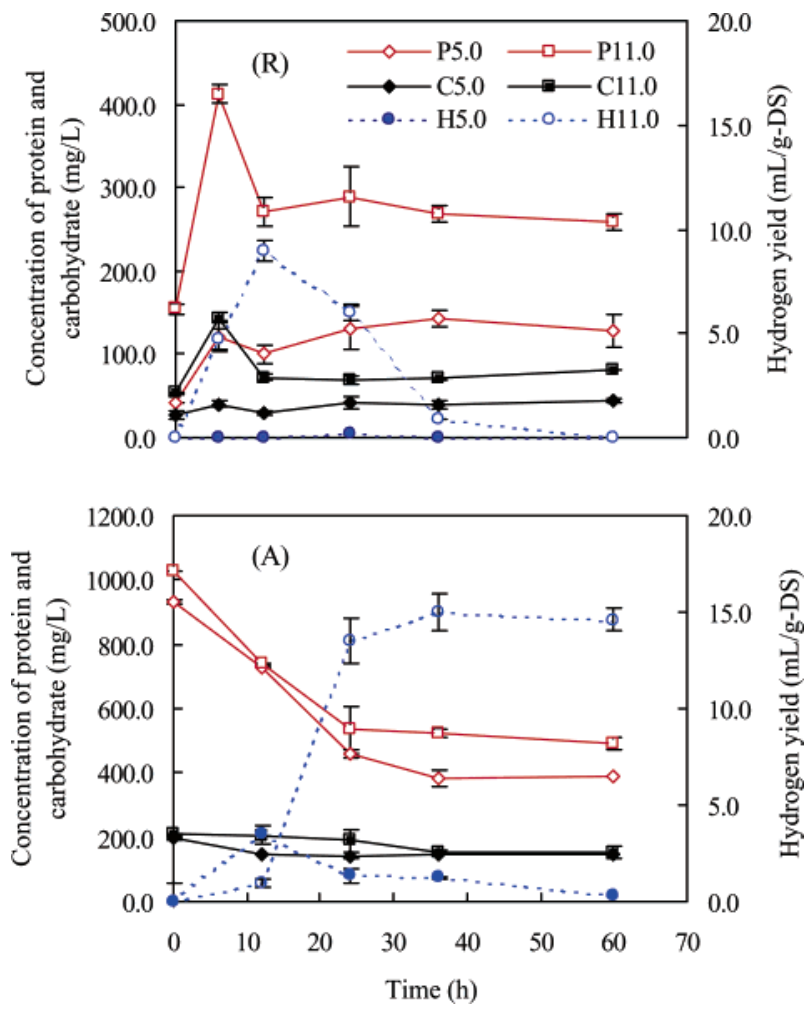

FIGURE 8. Changes of organic matters and hydrogen yield during biohydrogen fermentation from the raw sludge $(R)$ and the alkaline pretreated sludge (A). P5.0, C5.0, H5.0, P11.0, C11.0, and H11.0 refer to protein, carbohydrate concentrations, and hydrogen yields in the tests of initial $\mathrm{pH}$ at 5.0 and 11.0 , respectively.

mechanism of hydrogen production from sludgeathigh initial $\mathrm{pH}$.

Sewage sludge is mainly composed of microorganisms, and its organic substance composition is therefore different from carbohydrate-rich substrates such as glucose or starch. The domestic sludge consists of $41 \%$ protein, $25 \%$ lipid, $14 \%$ carbohydrate, and $20 \%$ unknown components on the basis of COD (28) or $32-41 \%$ protein and $5-12 \%$ fats on the basis of total dry solids (TDS) (26). Thus, protein is the largest constituent of the waste activated sludge. In thisstudy, soluble organic matters including protein, carbohydrates, and lipids of the raw sludgeand alkaline pretreated sludgewere analyzed at different initial $\mathrm{pH}$ values (Table 6). Obviously, all concentrations of three soluble organic mattersin thealkaline pretreated sludge were much higher than those in the raw sludge. The soluble protein was the major part of all three soluble organic matter. For the raw sludge, alkaline pretreatment was more effective for solubilizing organic matter than acidic pretreatment. For thealkaline pretreated sludge, the adjustment of $\mathrm{pH}$ had impact on soluble organic matter, and all three soluble organic matter at high initial $\mathrm{pH}$ of 11.0 were more than those at low initial pH of 5.0 (Table 6). So alkaline pretreatment of sewage sludge could provide more 


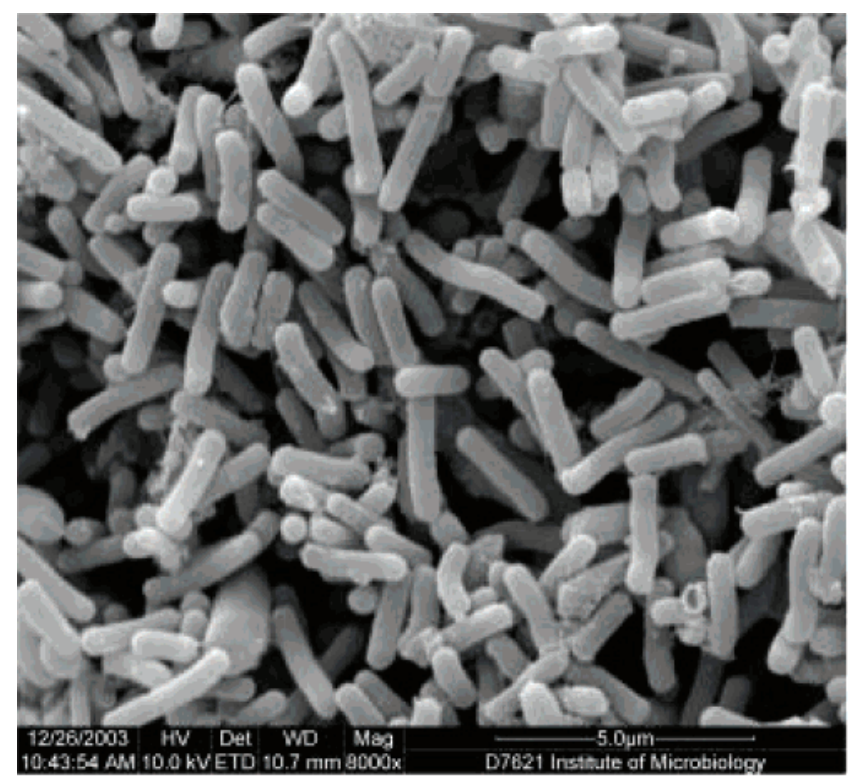

No.A1-1

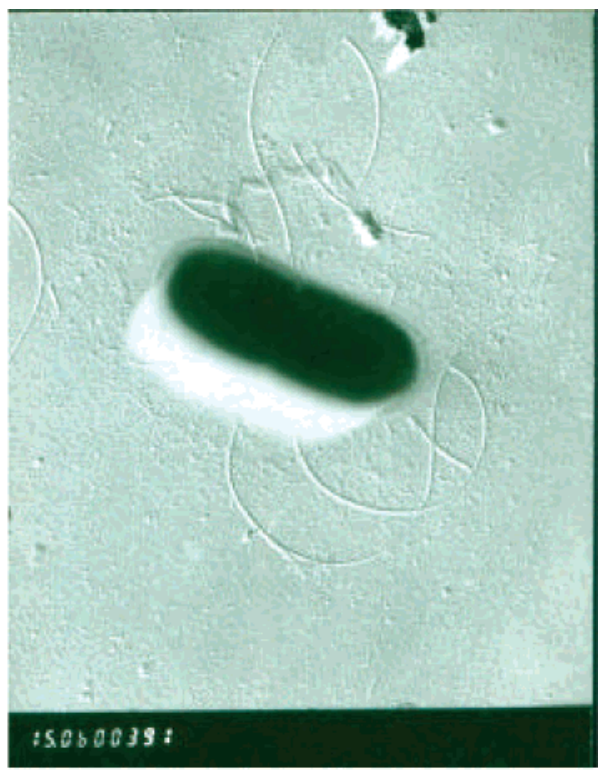

No.B3-1

FIGURE 9. Scanning electron microscopy (SEM) and transition electron microscopy (TEM) photographs of Eubacterium multiforme (No. A1-1) and Paenibacillus polymyxa (No. B3-1).

soluble organic matter for biohydrogen production from sewage sludge.

Because of hydrolysis, soluble protein and carbohydrate in the tests using raw sludge first increased to their maximal concentrations at $6 \mathrm{~h}$ and then gradually decreased. However, their concentrations were still higher at the end of the tests than at the beginning of the tests (Figure 8R). As shown in Figure 8A, it was obvious that no risein soluble organic matter occurred in biohydrogen production from the alkaline pretreated sludge at the initial $\mathrm{pH}$ values of 5.0 and 11.0, respectively. This phenomenon showed that the biohydrogen production from the raw sludge first experienced a hydrolysis process to solubilizeorganic matter but that using the alkaline pretreated sludge did not need such a process because of more existing bioavailableorganic matter. Hydrogen gas was produced correspondingly with an increase of solubleorganic matter and reached to its maximum at $12 \mathrm{~h}$ in the test using raw sludge at the initial $\mathrm{pH}$ of 11.0, but few hydrogen were detected in the test at an initial pH of 5.0. In the test of biohydrogen fermentation from alkaline pretreated sludge, the protein concentration sharply decreased in the first 24 $\mathrm{h}$ and then remained stable, but littlechangein carbohydrate concentration occurred throughout the period. Meanwhile, al most no changes in lipid werefound in both tests (data not shown in Figure 8). Compared with biohydrogen production from the al kal ine pretreated sludge at the initial $\mathrm{pH}$ of 11.0, both lower hydrogen yield and quicker hydrogen consumption were observed in the test of initial $\mathrm{pH}$ at 5.0, although a higher protein degradation rate $(58.8 \%)$ happened (Figure 8). These results clearly showed that protein was the major substratefor biohydrogen fermentation from sewage sludge, and thecombination of alkaline pretreatmentand high initial $\mathrm{pH}$ washelpful to inhibit the growth of hydrogen-consuming anaerobes and thus was able to maintain stable and high biohydrogen production from sewage sludge.

In the primary investigation of microflora, 14 strains of bacteria were screened, purified, and identified after biohydrogen production from the alkaline pretreated sludge at an initial pH of 11.0. The dominant bacteria were identified as Eubacterium multiforme and Penibacillus polymyxa (Figure 9). It is reported that E. multiforme can biodegrade peptone or glucose to produce acids and simultaneously generate hydrogen gas $(20,29)$. In our pure culture experi- ments, E. multiforme and P. polymyxa grew well in the $\mathrm{pH}$ range up to 9.0-9.5, but were inactive at $\mathrm{pH}$ less than 6.0. This result was consistent with results of biohydrogen production from the alkaline pretreated sludge at initial $\mathrm{pH}$ of 11.0. It also indicated that these bacteria could acclimatize themselves to the high $\mathrm{pH}$ condition during anaerobic fermentation. Compared with the results of $\mathrm{pH}$ changes mentioned in Table 5 and Figure 7, the microflora investigation showed that the combination of the high initial $\mathrm{pH}$ and the buffering capacity of sewage sludge could not only maintain a suitable $\mathrm{pH}$ range for the growth of dominant hydrogen-producing anaerobes but also inhibit the growth of hydrogen-consuming anaerobes. Further work is needed for the characterization of hydrogen fermentation of these dominant bacteria.

\section{Acknowledgments}

This study is financially supported by National Natural Science Foundation of China (No. 20277043).

\section{Literature Cited}

(1) Das, D.; Vezuriglu, T. N. Int. J. Hydrogen Energy 2001, 26, 1328.

(2) Van Ginkel, S.; Sung, S.; Lay, J. J. Environ. Sci. Technol. 2001, 35, 4726-4730.

(3) Mizuno, O.; Dinsdale, R.; Hawkes, F. R.; Hawkes, D. L.; Noike, T. Bioresour. Technol. 2000, 73, 59-65.

(4) StateEnvironmental Protection Administration of China. Chinese Environmental Statistical Gazetteof 2001; Beijing, China, 2001.

(5) Chen, C.-C.; Lin, C.-Y.; Lin, M.-C. Appl. Microbiol. Biotechnol. 2002, 58, 224-228.

(6) Logan, B. E.; Oh, S.-E.; Kim, I.-S.; Van Ginkel, S.; Environ. Sci. Technol. 2002, 36, 2530-2535.

(7) Lay, J. J.; Lee, Y. J.; Noike, T. Water. Res. 1999, 33 (11), 25792586.

(8) Tanisho, S.; Ishiwata, Y. Int. J. Hydrogen Energy 1995, 20 (7), $541-545$.

(9) Ueno, Y.; Kawai, T.; Sato, S.; Otsuka, S. Morimoto, M. J. Ferment. Bioeng. 1995, 79 (4), 395-397.

(10) Okamoto, M.; Milyahara, T.; Mizuno, O. Noike, T. Water Sci. Technol. 2000, 41 (3), 25-32.

(11) Wang, C.-C.; Chang, C.-W.; Chu, C.-P. J. Biotechnol. 2003, 102, 83-92. 
(12) Wang, C.-C.; Chang, C.-W.; Chu, C.-P.; Lee, D. J.; Chang, B. V.; Liao, C. S.; Tay, J. H. Water. Res. 2003, 37 (11), 2789-2793.

(13) Tanisho, S.; Ishiwata, Y. Int. J. Hydrogen Energy 1994, 19 (10), 807-812.

(14) Yokoi, H.; Tokushige, T.; Hirose, J.; Hayashi, S.; Takasaki, S. Biotechnol. Lett. 1998, 20 (2), 143-147.

(15) Taguchi, F.; Mizukami, N.; Tatsuo, S. T.; Hasegawa, K. Can. J. Microbiol. 1995, 41, 536-40.

(16) Fang, H. P.; Liu, H. Bioresour. Technol. 2002, 82, 87-93.

(17) Sung, S.; Raskin, L.; Duangmanee T.; Padmasiri, S.; Simmons, J.J. Proceedings of the2002 U.S. DOE Hydrogen Program Review; NREL/CO-610-32405.

(18) Lee, Y.; Miyahara, T.; Noike, T. J. Chem. Technol. Biotechnol. 2002, 77, 694.

(19) Owen, W. F.; Stuchey, D. C.; Healy, J. B., Jr.; Young, L. Y.; McCarty, P. L. Water Res. 1979, 13, 485-492.

(20) Zhu, D. X.; Cai, M. Y. Common Manual of Systematic Determinative Bacteriology, Chinese version; Beijing, China, 2001.

(21) Lowry, O. H.; Rowebrough, N. J.; Farr, A. L.; Randall, R. J. J. Biol. Chem. 1951, 193, 265-275.
(22) Dubois, M.; Gilles, K. A.; Hamilton, J. K.; Rebers, P. A.; Smith, F. Anal. Chem. 1956, 28, 350-356.

(23) Conrad, R. FEMS Microbiol. Ecol. 1999, 28, 193-202.

(24) Adams, M. W. W.; Edward, I. S. Science 1998, 282, 18421843.

(25) Cheng, S.-S.; Lin, C.-Y.; Lee, J.-M.; Tseng, I.-C.; Liu, W.-T.; Lin, M.-C. Ind. Pollut. Control 2001, 79, 173-193 (in Chinese).

(26) Weemaes, P.J. M.; Verstraete, W. H.J. Chem. Technol. Biotechnol. 1998, 73, 83-92

(27) Lin, C.-Y.; Lay, C. H. Int. J. Hydrogen Energy 2004, 29, 275-281.

(28) Tanaka, S.; Kobayashi, T.; Kamiyama, K.; Bildan, M. N. Water Sci. Technol. 1997, 35 (8), 209-215.

(29) Breed, R. S.; Murray, E. G. D.; Smith, N. R. Bergey's Manual of DerminativeBacteriology, 7th ed.; Tindall \& Cox, Ltd.: London, 1957.

Received for review August 20, 2003. Revised manuscript received February 18, 2004. Accepted March 19, 2004.

ES0349204 